\title{
Immunoreactivity and trypsin sensitivity of recombinant virus-like particles of foot-and-mouth disease virus
}

\author{
S. H. BASAGOUDANAVAR ${ }^{1}$, M. HOSAMANI ${ }^{1}$, R. P. TAMIL SELVAN ${ }^{1}$, P. SARAVANAN ${ }^{1}$, B. P. SREENIVASA ${ }^{1}$, \\ B. K. CHANDRASEKHAR SAGAR ${ }^{2}$, R. VENKATARAMANAN ${ }^{1 *}$
} ${ }^{1}$ ICAR-Indian Veterinary Research Institute, Hebbal, Bangalore 560024, India; ${ }^{2}$ Department of Neuropathology, NIMHANS,
Bangalore 560029, India

Received June 23, 2014; accepted February 18, 2015

\begin{abstract}
Summary. - Foot-and-mouth disease (FMD) is an important infection affecting the health and productivity of cloven-hoofed livestock. Development of improved vaccines and diagnostic reagents is being explored to facilitate the disease control. There is an emerging interest in virus-like particles (VLPs), as their constituent structural proteins are the major immunogens. The VLPs are similar to natural virus particles but lack viral nucleic acid. The objective of the present study was to express the VLPs of FMD virus (FMDV) serotype Asia-1 (IND 63/72), using baculovirus system and characterize them for antigenic structure. The VLPs expressed in insect cells showed immunoreactivity similar to inactivated cell culture FMDV. Further they possess similar sensitivity to trypsin as the inactivated cell culture FMDV, suggesting that trypsin-sensitive antigenic sites could be similarly arranged. Our findings suggest that the FMD VLPs have similar antigenic conformational feature like the wild type virus, thus supporting their utility in development of non-infectious FMD vaccines and/or diagnostic assays.
\end{abstract}

Keywords: foot-and-mouth disease virus; virus-like particle; bacmid; recombinant baculovirus; trypsin sensitivity; immunoreactivity

\section{Introduction}

Foot-and-mouth disease virus (FMDV), an animal virus of the family Picornaviridae causes highly transmittable acute infection in cloven-hoofed animals. In the endemic regions, FMD poses a severe menace to livestock industry. The disease affects productive capacity of animals though mortality rates are low in adult animals. Furthermore, it impinges on trade of animals and animal products, leading to huge economic losses. In India, the disease is endemic with recorded prevalence of serotypes $\mathrm{O}$, A and Asia-1, though seven antigenically distinct serotypes (O, A, C, Asia-1, SAT-1, SAT-2 and

*Corresponding author. E-mail: venkat1953@gmail.com; phone: +91-80-23412835.

Abbreviations: FMD $=$ foot-and-mouth disease; FMDV $=$ FMD virus; $\mathrm{VLP}=$ virus-like particle; $\mathrm{BVS}$ = bovine vaccinate serum
SAT-3) exist worldwide. Incidences of the disease due to serotype Asia-1 FMDV are mainly restricted to Asian continent. However, outbreaks due to this serotype were also recorded previously in parts of Europe as well (Valarcher et al., 2008, 2009). In Indian context, serotype Asia-1 accounts for significant proportion of the disease outbreaks after serotype O (Subramaniam et al., 2013). The FMDV has singlestranded positive sense RNA genome $(\sim 8.5 \mathrm{~kb})$ packaged in icosahedral capsid. The genome codes for a single open reading frame, leading to translation of a single polypeptide. The viral capsid precursor (P1-2A) (Palmenberg, 1990), initially translated as part of unprocessed polyprotein, is cleaved into four structural proteins - VP1, VP2, VP3 and VP4 (Curry et al., 1992; Fry et al., 2005) by viral 3C protease (Curry et al., 2007; Grubman et al., 2008), facilitating the structural proteins to assemble into empty capsid particles (Fry et al., 2005; Ko et al., 2005). The VP1 is the most exposed protein 
on the capsid in comparison to VP2 and VP3, and VP4 is known to be located internally (Morrell et al., 1987). The structural proteins constituting the capsid make the major immunogenic component of the virus and are associated with the production of virus-specific neutralizing antibodies. This makes the capsid a primary target in the design of a new generation vaccine or a sero-diagnostic reagent.

Preventive vaccination is the only available strategy for control of FMD in endemic countries. This necessitates the development of potent and durable vaccines, as well as reliable and easy-to-use diagnostic assays. Current FMD vaccines as well as sero-monitoring assays like liquid phase blocking ELISA use inactivated whole virus particles (OIE, 2012). However, when handling the infectious virus, there is a risk of improper virus inactivation and escape into the environment. To overcome the handling of infectious FMDV for biosafety concerns, virus-like particles (VLPs) lacking infectious genetic material can be generated by heterologous expression of the structural proteins using baculovirus expression system (Basagoudanavar et al., 2013; Cao et al., 2009; Lewis et al., 1991; Li et al., 2008, 2011; Porta et al., 2013).

Of the 3 serotypes used in Indian trivalent vaccine preparation, VLPs of type $\mathrm{O}$ and $\mathrm{A}$ were previously characterized (Basagoudanavar et al., 2013; Bhat et al., 2013). However no report is made with respect to serotype Asia-1 (IND 63/72). Previously it was demonstrated that trypsin-treatment of FMD virus particles results in reduction in their immunogenicity (Wild et al., 1969). Further, FMDV type Asia-1 is reported to have at least four trypsin-sensitive neutralizing antigenic sites, which are dependent on the native conformation of the virus (Sanyal et al., 1997). It is envisaged that FMD Asia-1 VLPs would have this conformational surface. Therefore, in the present study, we prepared recombinant VLPs of FMDV serotype Asia-1 using baculovirus expression system and characterized their immunoreactivity and trypsin sensitivity.

\section{Materials and Methods}

Cells and viruses. BHK-21 cells were maintained in Glasgow's modified Eagle's Medium (SAFC Biosciences, USA) supplemented with 10\% FBS. Serotype Asia-1 IND 63/72 of FMD vaccine virus strain was grown using BHK-21 cells. Sf-21 insect cells (Spodoptera frugiperda IPLB-Sf21-AE clone; Life Technologies, USA) were cultured in Sf-900 II SFM (Life Technologies) supplemented with 10\% FBS. Tn5 insect cells (Trichoplusia ni High-Five ${ }^{\mathrm{Ta}}$ BTI-TN-5B1-4; Life Technologies, USA) were cultured in Ex-Cell ${ }^{\mathrm{TM}} 405$ SFM (SAFC Biosciences, USA).

FMDV preparation and inactivation. Serotype Asia-1 IND 63/72 FMDV was propagated in BHK-21 cells. After complete cytopathic effect appeared, medium from infected culture was clarified by low speed centrifugation. Virus was inactivated by $1 \mathrm{mmol} / \mathrm{l}$ binary ethyleneimine (BEI).

Construction of expression vectors. Viral cDNA was prepared by reverse transcription using ThermoScript ${ }^{\mathrm{TM}}$ RT-PCR System (Life Technologies, USA), from RNA extracted from BHK-21 cell adapted FMDV. The cDNA was used as template for PCR amplification of P1-2A, using Pfu DNA polymerase (MBI Fermentas). PCR primers for amplification were designed using the nucleotide sequence of FMDV serotype Asia-1 IND 63/72 (GenBank Acc. No. AY304994.1). The primer pair consisted of VP4-F: 5'-TGGGATCCATGGGAGCYGGGCAATCCAG-3' and 2A-R: 5'-TGACTAGTCTCCACCAGYTTGGAGAaGT-3'. The P1-2A (full-length structural gene $\mathrm{P} 1$ including $2 \mathrm{~A}$ sequence) was cloned between BamHI and SpeI restriction sites of pFastBac-1 vector (Life Technologies, USA) to generate pFBac-As1-P1-2A. Full-length 3C region of FMDV serotype A IND 40/00 containing mutation C142T (Basagoudanavar et al., 2013) was ligated with pFBac-As1-P1-2A between SpeI and HindIII restriction sites. The recombinant transfer vector was designated as pFBac-As1-P1-2A-3 $\mathrm{C}^{142 \mathrm{~T}}$. The plasmid inserts were confirmed by automated DNA sequencing.

Generation of recombinant baculovirus. Recombinant bacmid DNA was obtained by transforming transfer vector into DH10$\mathrm{Bac}^{\mathrm{m}}$ competent cells (Life Technologies, USA), according to manufacturer's instructions. The recombinant bacmid was then transfected into Sf-21 insect cells by Cellfectin'II reagent (Life Technologies, USA). Following incubation at $26^{\circ} \mathrm{C}$ for $72-96 \mathrm{hr}$, supernatant containing recombinant baculovirus was harvested and stored at $4^{\circ} \mathrm{C}$. Recombinant baculovirus stocks were amplified and titrated by plaque assay before infection of Tn 5 cells to achieve high level expression of recombinant protein (Wickham and Nemerow, 1993).

Production and purification of FMDV VLPs. The Tn5 cells (at a density of $0.7 \times 10^{6}$ cells $/ \mathrm{ml}$ ) grown in $175 \mathrm{~cm}^{2}$ flasks containing 25 $\mathrm{ml}$ of medium were infected at a high MOI of 5, with recombinant baculovirus and harvested at day 4 post-infection. The cell containing medium was centrifuged at $800 \mathrm{rpm}$ for $10 \mathrm{~min}$. Cell pellet was resuspended in $2 \mathrm{ml}$ of Tris- $\mathrm{NaCl}(10 \mathrm{mmol} / \mathrm{l}$ Tris $\mathrm{pH} 7.5,130 \mathrm{mmol} / \mathrm{l} \mathrm{NaCl})$ buffer containing $1 \mathrm{mmol} / \mathrm{l} \mathrm{PMSF}$ with $0.1 \%$ Triton X-100. Cells were lysed by freezing and thawing three times and then passing through 21 $\mathrm{G}$ needle for 5-6 times using a syringe. Clarified supernatant containing recombinant VLPs was stored at $-80^{\circ} \mathrm{C}$.

Western blot assay. For detection of recombinant FMDV proteins, lysates from baculovirus infected $\mathrm{Tn} 5$ cells prepared in $2 \mathrm{x}$ SDS sample buffer were subjected to $12 \%$ bis-acrylamide SDS-PAGE. Gels were blotted onto a $0.45 \mu \mathrm{m}$ PVDF membrane and incubated at $4^{\circ} \mathrm{C}$ with rabbit anti-FMDV $146 \mathrm{~S}$ serum (1:100 dilution) of FMDV Asia-1 IND63/72, overnight. After washing the membrane, it was incubated with anti-rabbit IgG-HRPO conjugate (Dako, Denmark) (1:2,000 dilution) for $1 \mathrm{hr}$ at $37^{\circ} \mathrm{C}$, before developing with $\mathrm{DAB}$ substrate solution containing urea and $\mathrm{H}_{2} \mathrm{O}_{2}$.

Immunofluorescence assay. For detection of recombinant FMDV proteins, Tn5 cells expressing the FMDV Asia-1 P1-2A-3C were cultured as monolayer for 4 days, on glass cover slip placed in 
a 24-well plate and fixed with chilled methanol-acetone (1:1 ratio) at room temperature for $10 \mathrm{~min}$. Mock infected cells were used as control. Fixed cells were probed with 1:50 diluted rabbit anti-FMDV 146S (Asia-1) serum for $1 \mathrm{hr}$. After washing in PBS-T three times, samples were incubated with Alexa Fluor 488-conjugated goat anti-rabbit IgG (Molecular probes, 1:2,000 dilution) for $1 \mathrm{hr}$. After final washing, the cover slips were mounted on a glass-slide and cells were examined under fluorescence microscope.

Transmission electron microscopy. To verify the assembly of VLPs, Tn 5 cells infected with recombinant baculovirus were fixed in $3 \%$ glutaraldehyde in phosphate buffer ( $\mathrm{pH}$ 7.2) for $24 \mathrm{hr}$ and then post fixed in $1 \%$ osmium tetroxide for $1 \mathrm{hr}$ followed by dehydration in series of ethyl alcohol. Subsequently cleared in propylene oxide and embedded in pure araldite. Later, 400 to $500 \mathrm{~A}^{\circ}$ thick ultra thin sections collected on copper grids were stained using uranyl acetate and lead citrate as described earlier (Frasca and Parks, 1965). The dried copper grids were scanned under transmission electron microscope (Tecnai G2 Spirit Bio-twin-FEI Netherlands) at 80 KVA and representative images were captured using Megaview-III CCD camera.

Sandwich ELISA. Antigenic reactivity of the baculovirus expressed FMDV Asia-1 VLPs was analyzed by ELISA using hyperimmune sera raised in rabbit and guinea pig, against $146 \mathrm{~S}$ particles of FMDV Asia-1 IND 63/72, using protocol described previously (Basagoudanavar et al., 2013). For serotyping the VLP antigen, sandwich ELISA was carried out using rabbit and guinea pig antisera raised against type-specific inactivated $146 \mathrm{~S}$ virus antigens of serotypes $\mathrm{O}$, A and Asia-1.

Trypsin treatment. To analyse the sensitivity of VLPs in comparison with inactivated FMDV, they were treated with trypsin. Mature 146S particles of FMDV serotype Asia-1 were prepared by $\mathrm{CsCl}$ density gradient centrifugation and estimated by spectrophotometry (Wagner et al., 1970). Recombinant FMDV Asia-1 VLPs as well as BHK-21 cell culture-derived FMDV serotype Asia- 1 inactivated virus were quantified as $146 \mathrm{~S}$ equivalent by absorbance at $492 \mathrm{~nm}$ in sandwich ELISA. Trypsin-treated antigens were prepared as described previously (Sanyal et al., 1997). Briefly, to $1 \mu \mathrm{g}$ of $146 \mathrm{~S}$ particles equivalent VLP or cell culture antigen, $1 \mu \mathrm{g}$ of trypsin (from stock solution of $2 \mathrm{mg} / \mathrm{ml}$ in $0.1 \mathrm{~mol} / \mathrm{l}$ phosphate buffer, $\mathrm{pH} 7.4$ ) was added and incubated at $37^{\circ} \mathrm{C}$ for $15 \mathrm{~min}$. The reaction was stopped by the addition of $1 \mu \mathrm{g}$ of soybean trypsin inhibitor.

Inhibition ELISA. To analyse the capacity of VLPs in inhibiting the reactivity of bovine vaccinate serum (BVS) with viral antigen, the inhibition ELISA was carried out. The inhibition ELISA was adapted from a previous report (Azfar and Islam, 2012). Briefly, guinea pig antisera (1:3000 dilution) raised against inactivated $146 \mathrm{~S}$ of FMDV Asia-1 antigen was used for coating. The ELISA plate was blocked with $3 \%$ skimmed milk in PBS containing $0.05 \%$ Tween-20 and incubated with PEG precipitated cell culture FMDV Asia-1 antigen. In the meantime, equivalent cell culture FMDV Asia-1 antigen and recombinant VLP antigen, separately were incubated in liquid phase with 1:16 diluted BVS having SN titre 256 , at $37^{\circ} \mathrm{C}$ for $1 \mathrm{hr}$. Subsequently, the BVS was added to the plate to allow reaction with PEG precipitated cell culture antigen bound to the plate. The bound antibodies were assayed using anticow HRP conjugate (Dako, Denmark) at a dilution of 1:3,000. After final washing, color was developed using freshly prepared orthophenylene diamine/hydrogen peroxide chromogen substrate and incubated for $15 \mathrm{~min}$. The color reaction was stopped by adding $1 \mathrm{~mol} / \mathrm{L} \mathrm{H}_{2} \mathrm{SO}_{4}$ Absorbance at $492 \mathrm{~nm}$ was measured in an ELISA plate reader (Tecan Infinite50) and inhibition in reactivity of the BVS with plate bound antigen was calculated.

Statistical analysis. Student's unpaired t-test was used for comparison of means between control and experimental groups.

\section{Results}

\section{Expression of FMDV precursor polypeptide in insect cells}

Insect cells ( $\mathrm{Tn} 5)$ were infected with recombinant baculovirus encoding FMDV (serotype Asia-1) P1-2A, at MOI of 5. The lysates of 4 day infected cells were analyzed by western blotting using rabbit serum raised against purified $146 \mathrm{~S}$ FMDV serotype Asia-1. An expected size protein band with a molecular mass of $\sim 86 \mathrm{kDa}$ (Fig. 1e, lane 1) corresponding to $\mathrm{P} 1-2 \mathrm{~A}$ polypeptide band was present. Upon fusion of $3 \mathrm{C}$ that contained $\mathrm{C} 142 \mathrm{~T}$ substitution, with $\mathrm{P} 1-2 \mathrm{~A}$, the resulting recombinant baculovirus encoding FMDV P1-2A-3C ${ }^{142} \mathrm{~T}$ showed bands corresponding to accumulation of VP0,VP3 and VP1 structural proteins (Fig. 1e, lane 2). Further, insect cells expressing P1-2A-3 $\mathrm{C}^{142 \mathrm{~T}}$ showed detectable fluorescence after incubation with rabbit serum raised against purified 146S FMDV serotype Asia-1 (Fig. 1a).

\section{Self-assembly of VLPs}

Tn 5 cells infected with recombinant baculovirus encoding FMDV P1-2A-3 $\mathrm{C}^{142 \mathrm{~T}}$ were harvested at day 4 post infection and processed for Transmission electron microscopy upon positive staining. Empty capsid particles were observed in the cytoplasm of Tn 5 cells, located in endosomal structures. The size of the empty capsids was about 25-30 nm (Fig. 2a and b), which is expected for FMDV particles. This suggested that the recombinant VLPs are formed following self-assembly of structural proteins and they are morphologically similar to authentic FMDV empty capsid particles.

\section{Immunoreactivity of VLPs}

To assess the reactivity of the recombinant empty capsids in comparison to authentic FMDV virus particles, sandwich ELISA was carried out. Hyperimmune sera against purified 146S FMDV Asia-1 raised in rabbit and guinea pig were used as capture and detector antibody, respectively. The 
recombinant empty capsids showed reactivity with these homotypic anti-146S antibodies, comparable to inactivated FMDV antigen (Fig. 3a), suggesting that the baculovirus expressed empty capsid has antigenic features comparable to authentic FMDV particle. Further, serotyping ELISA confirmed the serotype specificity of the VLPs indicated by strong reaction with homotypic Asia-1 146S specific antisera, and least cross reactivity with serotype $O$ or serotype A specific sera (Fig. 3b).

Comparative effect of trypsin on immunoreactivity of VLPs and cell culture-derived virus

When equivalent amount of VLPs and cell culture-derived FMD Asia-1 virus antigen were treated with increasing concentrations of trypsin, the reactivity of both antigens with homotypic sera in a sandwich ELISA gradually decreased, subsequently reaching plateau beyond $0.75 \mu \mathrm{g} / \mu \mathrm{g}$ of antigen (Fig. 4a). This showed that VLPs have similar sensitivity to trypsin as the FMDV.

Comparative performance of VLPs and cell cultrurederived virus in inhibiting the reactivity of bovine vaccinate serum with viral antigen

In inhibition ELISA, recombinant VLPs as well as cell culture-derived virus antigen inhibited the reactivity of bovine vaccinate serum (SN titre 256) with PEG precipitated FMDV antigen bound to the plate. The inhibition was relatively higher with the former, however with no significant difference between the two. Upon trypsin treatment $(1 \mu \mathrm{g} /$ $\mu \mathrm{g}$ of antigen) of the inhibitory antigens, the inhibition in reactivity of the BVS to the plate bound FMDV antigen was significantly ( $\mathrm{p}<0.05$ ) and proportionately reduced (Fig. $4 \mathrm{~b})$. This suggested that trypsin sensitive antigenic sites of the VLPs are similarly arranged as the native Asia-1 FMDV, indicating likely conformational resemblance of neutralizing antigenic sites.

\section{Discussion}

Considering the risks associated with handling infectious virus, the baculovirus expressed empty capsids could potentially serve as non-infectious alternative for the cell culturederived FMDV antigen for use as vaccine and/or as diagnostic reagent. Expression of VLPs obviates the need to produce the antigens in expensive high containment production set up. Therefore, attempts have been made to express FMDV empty capsids (Basagoudanavar et al., 2013; Cao et al., 2009; Gullberg et al., 2013; Ko et al., 2009, 2010; Oem et al., 2007; Porta et al., 2013). FMD viruses however, have structural proteins that are serotype specific. This demands the de-
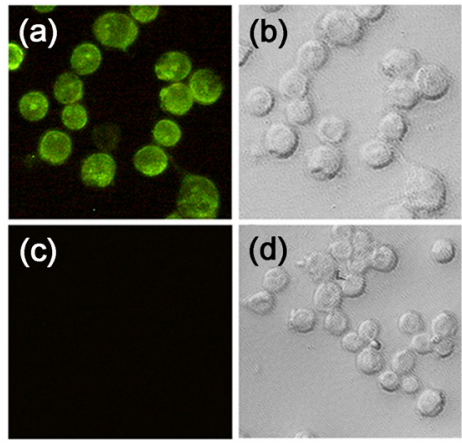

(d)

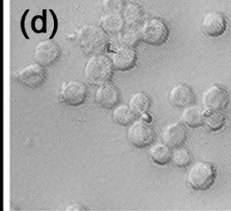

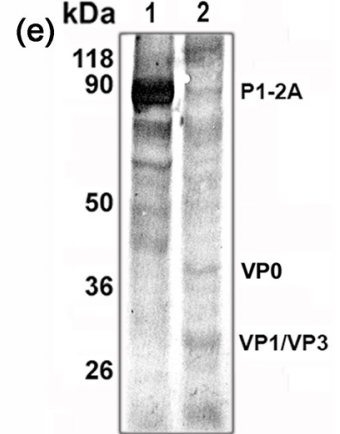

Fig. 1

Analysis of expression of FMDV precursor polypeptide Indirect immunofluorescence assay of $\mathrm{Tn} 5$ cells infected with recombinant baculovirus encoding P1-2A-3 $\mathrm{C}^{142 \mathrm{~T}}$ : fluorescent image of P1-2A-3 $\mathrm{C}^{142 \mathrm{~T}}$ (a) and corresponding bright light image (b); fluorescent and bright light images of negative control (c, d); (e) Western bolt analysis of lysate of Tn5 cells infected with recombinant baculovirus encoding P1-2A (lane 1) and P1-2A3-3C C $^{142 \mathrm{~T}}$ (lane 2)

(a)

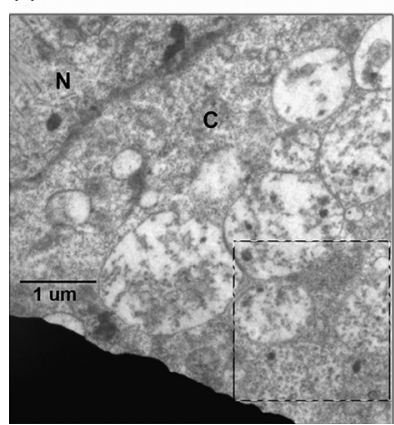

(b)

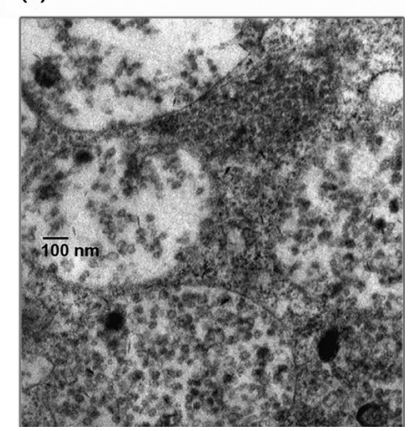

Fig. 2

Electron microscopy of Tn5 cells infected with recombinant baculovirus $\mathrm{P1}-2 \mathrm{~A}-3 \mathrm{C}^{142 \mathrm{~T}}$.

(a) Stained empty capsids (nucleus (N), cytoplasm (C)). (b) Magnified view of the part highlighted in (a). Empty capsids are located in endosomal structures in the cytoplasm.

velopment of VLPs for all of the serotypes in geographical contexts with multiple serotype prevalence. Previously, VLP expression of Asia I/JS/2005 strain (China) of FMDV was reported (Cao et al., 2009) using the pFastBac ${ }^{\mathrm{Tm}}$ Dual vector containing two multiple cloning sites, where P1-2A was under polyhedrin promoter and $3 \mathrm{C}$ under p10 promoter. Also the capsid (P1-2A) and 3C of FMDV Asia I/HNK/CHA/05 strain of Hong Kong and China were expressed using silkworm baculovirus (Li et al., 2008). To our knowledge there is no report on the generation of VLPs for FMDV Asia-1 IND $63 / 72$, one of the strains used in Indian vaccine formulations. In the present study, we produced VLPs of FMDV Asia-1 IND 63/72 in insect cells by expressing P1-2A-3C fusion protein under polyhedrin promoter utilizing baculovirus 
(a)

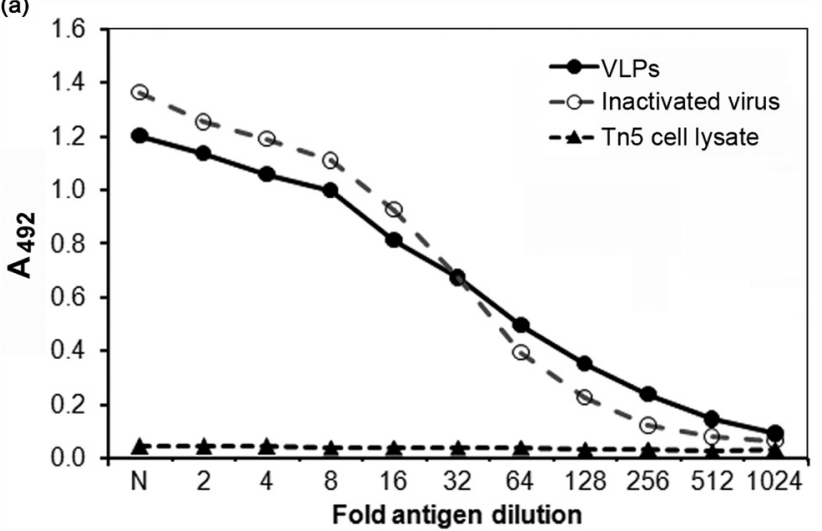

(b)

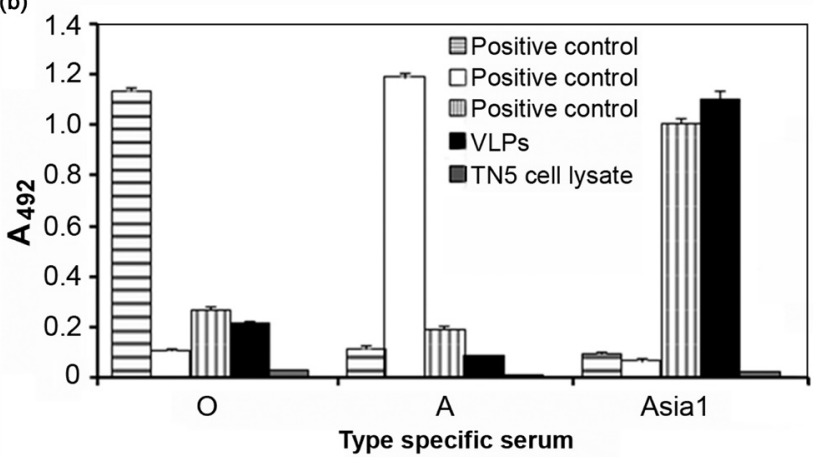

Fig. 3

Immunoreactivity and serotyping of recombinant VLPs in sandwich ELISA

(a) Reactivity of indicated antigens with homotypic sera. (b) Serotypespecific reactivity of recombinant VLPs.

expression system. The P1-2A itself produced FMDV specific antigen of the size of $\sim 86 \mathrm{kDa}$. The P1-2A-3C contained fusion of $3 \mathrm{C}$, in frame with the $\mathrm{C}$ terminus of P1-2A. A 18 aa sequence of $2 \mathrm{~A}$ together with eight $\mathrm{N}$-terminal residues of 2B was included downstream of precursor polypeptide P1, to allow recognition of $2 \mathrm{~A} / 2 \mathrm{~B}$ junction by $2 \mathrm{~A}$ polypeptide and separate itself from whole polypeptide following cleavage of P1/2A junction by 3C (Donnelly et al., 1997; Toyoda et al., 1986). Eight C-terminal residues of 3B3 were included upstream of $3 \mathrm{C}$ sequence to facilitate its self cleavage in the polypeptide (Birtley et al., 2005). The released 3C protease would subsequently process $\mathrm{P} 1$ to VP0, VP3 and VP1, allowing them to assemble into FMDV empty capsids (Goodwin et al., 2009). However, when P1-2A-3C was expressed, there were no detectable structural proteins in western blot, due to hyper protease activity of $3 \mathrm{C}$ as shown previously (Basagoudanavar et al., 2013). Therefore, to moderate its proteolytic activity, an amino acid substitution $\mathrm{C} 142 \mathrm{~T}$ was included in

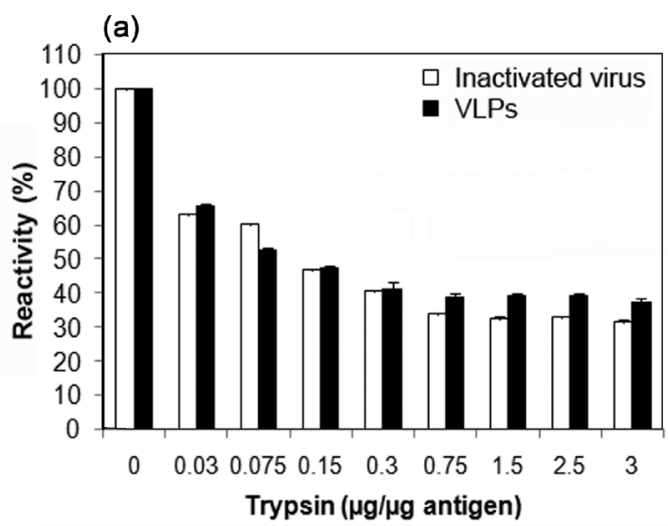

(b)

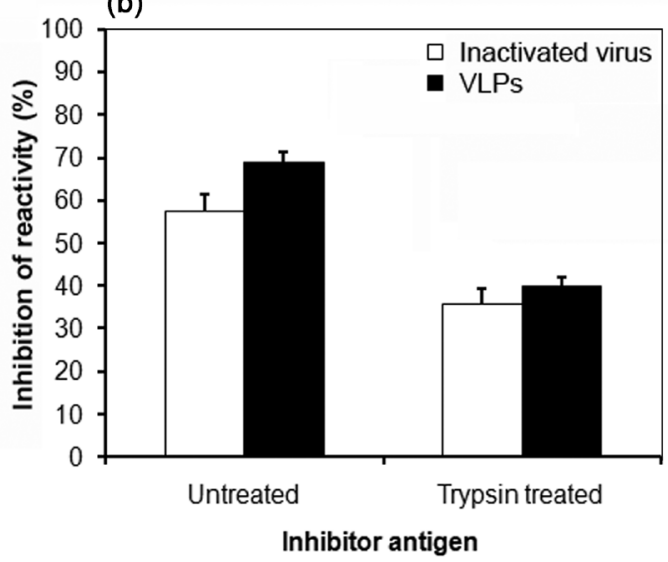

Fig. 4

Trypsin sensitivity and reactivity of recombinant VLPs and cell culture-derived viral antigen in sandwich ELISA

(a) Reactivity of recombinant VLPs and cell culture-derived viral antigen (treated with indicated amount of trypsin) with homotypic sera. (b) Inhibition of the reactivity of BVS with with PEG-precipitated viral antigen by VLPs and cell culture-derived viral antigen (both treated or untreated with trypsin).

3C sequence (Sweeney et al., 2007). This resulted in optimal processing of $\mathrm{P} 1$ polypeptide, thus resulting in accumulation of processed subunits expected for VP1, VP3 and VP0. The 3C of serotype A (IND 40/00) was efficiently used to process P1-2A of serotype Asia-1 in the present work, as the FMD viruses share a high degree of overall $3 \mathrm{C}$ conservation (Carrillo et al., 2005).

Upon examination under a transmission electron microscope, the recombinant empty capsid structures of heterogenous sizes ranging from $25-30 \mathrm{~nm}$ were concentrated in endosomal structures within the cytoplasm of insect cells. This is in concurrence with earlier observation that FMDV particles locate into endosomes in the cytoplasm of infected BHK-Op48 cells (Huang et al., 2011). Taken together, our data demonstrate that expression of precursor polypeptide and mutant $3 \mathrm{C}$ in a single frame resulted in the production of structural proteins that self assembled into empty FMDVlike particles. The results of sandwich ELISA demonstrated 
that the expressed empty capsid particles strongly reacted with homotypic anti-146S serum, suggesting that they mimic antigenicity similar to that of native serotype Asia-1 FMDV particles.

It has been established earlier that ability of mature FMD virus (146S) particles to stimulate neutralizing antibody response is significantly affected upon treatment with trypsin (Wild and Brown, 1967). It has been further demonstrated that in type Asia-1 virus, the trypsin-sensitive neutralizing antigenic sites are dependent on its native conformation (Sanyal et al., 1997). We have therefore analysed the pattern of trypsin sensitivity of recombinant VLPs and effect of trypsin on immunoreactivity. We showed that trypsin treatment of VLPs similar to that of cell culture-derived FMDV antigen reduces the immunoreactivity with known positive serum raised against $146 \mathrm{~S}$ of FMDV Asia-1. However, after reaching certain concentration of trypsin, reactivity remained stable with both antigens, possibly due to the contribution of trypsin insensitive antigenic determinants. These results indicate that VLPs have similar sensitivity to trypsin like the inactivated FMDV Asia-1. To our knowledge, this study provides the first demonstration of trypsin sensitivity and related antigenic facet of recombinant VLPs.

Considering the importance of conformational features of the capsid, we carried out inhibition step in liquid phase incubation for inhibition ELISA. Both recombinant VLPs and native virus antigen inhibited bovine vaccinate serum (SN titre of 256), reducing its binding to homotypic antigen. Interestingly, trypsin treatment of the VLPs significantly reduced their capacity to inhibit neutralizing antibodies of BVS. These data suggest that the VLPs have similar conformational arrangement of neutralizing determinants like authentic FMDV. Further studies are warranted to characterize the neutralizing epitopes of VLPs, using monoclonal antibodies.

In conclusion, our findings demonstrate that expression of structural polypeptide and mutant $3 \mathrm{C}$ resulted in the production of structural proteins that self assembled into FMDV-like particles. The insect cell expressed VLPs of FMDV Asia-1 have similar antigenic feature as the native virus and thus would contribute to the development of safe and novel vaccine and/or diagnostic reagent useful in FMD control programme.

Acknowledgements. Authors are thankful to the Director, Indian Veterinary Research Institute (IVRI), Izatnagar, for providing necessary facilities to carry out this work.

\section{References}

Azfar SF, Islam N (2012): Suppression of mycobacterium tuberculosis induced reactive oxygen species and tumor necrosis factor-alpha activity in human monocytes of systemic lupus erythematosus patients by reduced glutathione. Oman Med. J. 27, 11-19. http://dx.doi.org/10.5001/ omj.2012.03

Basagoudanavar SH, Hosamani M, Tamil Selvan RP, Sreenivasa BP, Saravanan P, Chandrasekhar Sagar BK, Venkataramanan $\mathrm{R}$ (2013): Development of a liquid-phase blocking ELISA based on foot-and-mouth disease virus empty capsid antigen for seromonitoring vaccinated animals. Arch. Virol. 158, 993-1001. http://dx.doi.org/10.1007/s00705$\underline{012-1567-5}$

Bhat SA, Saravanan P, Hosamani M, Basagoudanavar SH, Sreenivasa BP, Tamilselvan RP, Venkataramanan R (2013): Novel immunogenic baculovirus expressed virus-like particles of foot-and-mouth disease (FMD) virus protect guinea pigs against challenge. Res. Vet. Sci. 95, 1217-1223. http:// dx.doi.org/10.1016/j.rvsc.2013.07.007

Birtley JR, Knox SR, Jaulent AM, Brick P, Leatherbarrow RJ, Curry S (2005): Crystal structure of foot-and-mouth disease virus $3 \mathrm{C}$ protease. New insights into catalytic mechanism and cleavage specificity. J. Biol. Chem. 280, 11520-11527. http://dx.doi.org/10.1074/jbc.M413254200

Cao Y, Lu Z, Sun J, Bai X, Sun P, Bao H, Chen Y, Guo J, Li D, Liu X, Liu Z (2009): Synthesis of empty capsid-like particles of Asia I foot-and-mouth disease virus in insect cells and their immunogenicity in guinea pigs. Vet. Microbiol. 137, 10-17. http://dx.doi.org/10.1016/j.vetmic.2008.12.007

Carrillo C, Tulman ER, Delhon G, Lu Z, Carreno A, Vagnozzi A, Kutish GF, Rock DL (2005): Comparative genomics of foot-and-mouth disease virus. J. Virol. 79, 6487-6504. http://dx.doi.org/10.1128/JVI.79.10.6487-6504.2005

Curry S, Abu-Ghazaleh R, Blakemore W, Fry E, Jackson T, King A, Lea S, Logan D, Newman J, Stuart D (1992): Crystallization and preliminary $\mathrm{X}$-ray analysis of three serotypes of foot-and-mouth disease virus. J. Mol. Biol. 228, 12631268. http://dx.doi.org/10.1016/0022-2836(92)90332-E

Curry S, Roque-Rosell N, Sweeney TR, Zunszain PA, Leatherbarrow RJ (2007): Structural analysis of foot-and-mouth disease virus $3 \mathrm{C}$ protease: a viable target for antiviral drugs? Biochem. Soc. Trans. 35, 594-598. http://dx.doi. org/10.1042/BST0350594

Donnelly ML, Gani D, Flint M, Monaghan S, Ryan MD (1997): The cleavage activities of aphthovirus and cardiovirus 2A proteins. J. Gen. Virol. 78, 13-21.

Frasca JM, Parks VR (1965): A routine technique for doublestaining ultra-thin sections using uranyl and lead salts. J. Cell Biol. 25, 157-161. http://dx.doi.org/10.1083/ jcb.25.1.157

Fry, EE, Stuart DI, Rowlands DJ (2005): The structure of foot-andmouth disease virus. Curr. Top. Microbiol. Immunol. 288, 71-101. http://dx.doi.org/10.1007/3-540-27109-0 4

Goodwin S, Tuthill TJ, Arias A, Killington RA, Rowlands DJ (2009): Foot-and-mouth disease virus assembly: processing of recombinant capsid precursor by exogenous protease induces self-assembly of pentamers in vitro in a myristoylation-dependent manner. J. Virol. 83, 11275-11282. http://dx.doi.org/10.1128/JVI.01263-09

Grubman MJ, Moraes MP, Diaz-San Segundo F, Pena L, de los Santos T (2008): Evading the host immune response: how 
foot-and-mouth disease virus has become an effective pathogen. FEMS Immunol. Med. Microbiol. 53, 8-17. http://dx.doi.org/10.1111/j.1574-695X.2008.00409.x

Gullberg M, Muszynski B, Organtini LJ, Ashley RE, Hafenstein SL, Belsham GJ, Polacek C (2013): Assembly and characterization of foot-and-mouth disease virus empty capsid particles expressed within mammalian cells. J. Gen. Virol. 94, 1769-1779. http://dx.doi.org/10.1099/vir.0.054122-0

Huang X, Li Y, Fang H, Zheng C (2011): Establishment of persistent infection with foot-and-mouth disease virus in BHK-21 cells. Virol. J. 8, 169. http://dx.doi.org/10.1186/1743$\underline{422 X-8-169}$

Ko YJ, Choi KS, Nah JJ, Paton DJ, Oem JK, Wilsden G, Kang SY, Jo NI, Lee JH, Kim JH, Lee HW, Park JM (2005): Noninfectious virus-like particle antigen for detection of swine vesicular disease virus antibodies in pigs by enzyme-linked immunosorbent assay. Clin. Diagn. Lab. Immunol. 12, 922-929.

Ko YJ, Jeoung HY, Lee HS, Chang BS, Hong SM, Heo EJ, Lee KN, Joo HD, Kim SM, Park JH, Kweon CH (2009): A recombinant protein-based ELISA for detecting antibodies to foot-and-mouth disease virus serotype Asia 1. J. Virol. Methods 159, 112-118. http://dx.doi.org/10.1016/j. jviromet.2009.03.011

Ko YJ, Lee HS, Jeoung HY, Heo EJ, Ko HR, Chang BS, Joo HD, Gerelmaa U, Dashzeveg B, Tserendorj S, Sodnomdarjaa R, Park JH, Kweon CH, Cho IS, Paik SG (2010): Use of a baculovirus-expressed structural protein for the detection of antibodies to foot-and-mouth disease virus type A by a blocking enzyme-linked immunosorbent assay. Clin Vaccine Immunol. 17, 194-198. http://dx.doi.org/10.1128/ CVI.00374-09

Lewis SA, Morgan DO, Grubman MJ (1991): Expression, processing, and assembly of foot-and-mouth disease virus capsid structures in heterologous systems: induction of a neutralizing antibody response in guinea pigs. J. Virol. $65,6572-6580$

Li Z, Yi Y, Yin X, Zhang Z, Liu J (2008): Expression of foot-andmouth disease virus capsid proteins in silkworm-baculovirus expression system and its utilization as a subunit vaccine. PLoS One 3, e2273. http://dx.doi.org/10.1371/ journal.pone. 0002273

Li Z, Yin X, Yi Y, Li X, Li B, Lan X, Zhang Z, Liu J (2011): FMD subunit vaccine produced using a silkworm-baculovirus expression system: protective efficacy against two type Asia-1 isolates in cattle. Vet. Microbiol. 149, 99-103. http://dx.doi.org/10.1016/j.vetmic.2010.10.022

Morrell DJ, Mellor EJ, Rowlands DJ, Brown F (1987): Surface structure and RNA-protein interactions of foot-and-mouth disease virus. J. Gen. Virol. 68, 1649-1658. http://dx.doi. org/10.1099/0022-1317-68-6-1649

Oem JK, Park JH, Lee KN, Kim YJ, Kye SJ, Park JY, Song HJ (2007): Characterization of recombinant foot-and-mouth disease virus pentamer-like structures expressed by baculovirus and their use as diagnostic antigens in a blocking ELISA. Vaccine 25, 4112-4121. http://dx.doi.org/10.1016/j. vaccine. 2006.08 .046
OIE (2012): Foot-and-mouth disease. In OIE manual of diagnostic tests and vaccines for terrestrial animals. Paris, France, chapter 2. 1.5.

Palmenberg AC (1990): Proteolytic processing of picornaviral polyprotein. Annu. Rev. Microbiol. 44, 603-623. http:// dx.doi.org/10.1146/annurev.mi.44.100190.003131

Porta C, Xu X, Loureiro S, Paramasivam S, Ren J, Al-Khalil T, Burman A, Jackson T, Belsham GJ, Curry S, Lomonossoff GP, Parida S, Paton D, Li Y, Wilsden G, Ferris N, Owens R, Kotecha A, Fry E, Stuart DI, Charleston B, Jones IM (2013): Efficient production of foot-and-mouth disease virus empty capsids in insect cells following down regulation of 3C protease activity. J. Virol. Methods 187, 406-412. http://dx.doi.org/10.1016/j.jviromet.2012.11.011

Sanyal A, Venkataramanan R, Pattnaik B (1997): Antigenic features of foot-and-mouth disease virus serotype Asia-1 as revealed by monoclonal antibodies and neutralizationescape mutants. Virus Res. 50, 107-117. http://dx.doi. org/10.1016/S0168-1702(97)00058-0

Subramaniam S, Pattnaik B, Sanyal A, Mohapatra JK, Pawar SS, Sharma GK, Das B, Dash BB (2013): Status of footand-mouth disease in India. Transbound. Emerg. Dis. 60, 197-203. http://dx.doi.org/10.1111/j.1865-1682 .2012.01332.x

Sweeney TR, Roque-Rosell N, Birtley JR, Leatherbarrow RJ, Curry $S$ (2007): Structural and mutagenic analysis of foot-andmouth disease virus $3 \mathrm{C}$ protease reveals the role of the beta-ribbon in proteolysis. J. Virol. 81, 115-124. http:// dx.doi.org/10.1128/JVI.01587-06

Toyoda H, Nicklin MJ, Murray MG, Anderson CW, Dunn JJ, Studier FW, Wimmer E (1986): A second virus-encoded proteinase involved in proteolytic processing of poliovirus polyprotein. Cell 45, 761-770. http://dx.doi. org/10.1016/0092-8674(86)90790-7

Valarcher JF, Knowles NJ, Zakharov V, Scherbakov A, Zhang Z, Shang YJ, Liu ZX, Liu XT, Sanyal A, Hemadri D, Tosh C, Rasool TJ, Pattnaik B, Schumann KR, Beckham TR, Linchongsubongkoch W, Ferris NP, Roeder PL, Paton DJ (2009): Multiple origins of foot-and-mouth disease virus serotype Asia 1 outbreaks, 2003-2007. Emerg. Infect. Dis. 15, 1046-1051. http://dx.doi.org/10.3201/ eid1507.081621

Valarcher JF, Leforban Y, Rweyemamu M, Roeder PL, Gerbier G, Mackay DK, Sumption KJ, Paton DJ, Knowles NJ (2008): Incursions of foot-and-mouth disease virus into Europe between 1985 and 2006. Transbound. Emerg. Dis. 55, 14-34. http://dx.doi.org/10.1111/j.1865-1682 $.2007 .01010 . \mathrm{x}$

Wagner GG, Card JL, Cowan KM (1970): Immunochemical studies of foot-and-mouth disease. VII. Characterization of footand-mouth disease virus concentrated by polyethylene glycol precipitation. Arch. Gesamte. Virusforsch. 30, 343-352. http://dx.doi.org/10.1007/BF01258364

Wickham TJ, Nemerow GR (1993): Optimization of growth methods and recombinant protein production in BTI-Tn-5B1-4 insect cells using the baculovirus expression system. Biotechnol. Prog. 9, 25-30. http://dx.doi.org/10.1021/ bp00019a004 
Wild TF, Brown F (1967): Nature of the inactivating action of trypsin on foot-and-mouth disease virus. J. Gen. Virol. 1, 247-250. http://dx.doi.org/10.1099/0022-1317-1-2-247
Wild TF, Burroughs JN, Brown F (1969): Surface structure of footand-mouth disease virus. J. Gen. Virol. 4, 313-320. http:// dx.doi.org/10.1099/0022-1317-4-3-313 